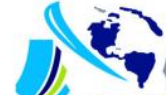 Journal BiNET}

Journal of Bioscience and Agriculture Research

Home page: www.journalbinet.com/jbar-journal.html

\title{
Yield of rice in response of shade and orientation
}

\author{
Rumana Shammia, Md. Rishad Abdullah ${ }^{\mathrm{a}}$ and Md. Mustafizur Rahman ${ }^{\mathrm{b}}$ \\ Dept. of Agroforestry, Bangladesh Agricultural University (BAU) \\ ${ }^{b}$ Dept. of Crop Botany, Bangladesh Agricultural University (BAU), Mymensingh, Bangladesh
}

\begin{abstract}
To find out shading effect of some selected tree species and different orientations on the yield and yield attributes of rice $\mathrm{cv}$ BR11 in agro forestry system an experiment was laid out in two factorial, Randomized Complete Block Design with three replications. Rice was grown in different orientations around the tree of Albida, Akashmoni and Jhau (North, South, East and West orientations), as the orientations were made $1 \mathrm{~m}$ apart from the tree base. The effect of tree-rice association was found significant on plant height, effective tillers hill-1, non-effective tillers hill-1, effective grains panicle ${ }^{-1}$, sterile spikelets panicle-1, total grain $\left(t \mathrm{ha}^{-1}\right)$ and straw yield $\left(t \mathrm{ha}^{-1}\right)$. It was recorded that out of the three tree-rice association, the highest yield (4.88 $t \mathrm{ha}^{-1}$ ) was found under Albida and the lowest yield (4.70 $t$ ha $^{-1}$ ) was found under Akashmoni that was statistically similar with Jhau. The highest (7.10 $\left.t \mathrm{ha}^{-1}\right)$ and lowest (6.80 $t \mathrm{ha}^{-1}$ ) straw yield were found under Albida and Akashmoni. The highest plant height $(105.75 \mathrm{~cm})$, effective tillers hill-1 ${ }^{11.85)}$, non-effective tillers hill-1 (1.91), effective grains panicle-1 (140.65), and sterile spikelet panicle ${ }^{-1}$ (29.88) were found under the Albida. Regarding different orientations from the tree base, the plant height, effective tillers hill-1, noneffective tillers hill-1, effective grains panicle ${ }^{-1}$ and grain yield $\left(t h^{-1}\right)$ of rice were significant. The highest grain yield (4.86 tha-1) of rice was obtained at the north orientation and the lowest grain yield ( $4.60 \mathrm{t} \mathrm{ha}^{-1}$ ) of rice was obtained at the west orientation, while significantly highest grain yield (5.00 $\left.\mathrm{t} \mathrm{ha}^{-1}\right)$ was found in control. All parameters produced the highest performance in open field compared to tree-rice association in respect of orientation.
\end{abstract}

Keywords: Shade, orientation, Albida, Akashmoni, Jhau and rice

Please cite this article as: Shammi, R., Abdullah, M. R. \& Rahman, M. M. (2016). Yield of rice in response of shade and orientation. Journal of Bioscience and Agriculture Research, 06(02), 547-552.

This article is distributed under terms of a Creative Common Attribution 4.0 International License.

\section{Introduction}

Forest plays a vital role in maintaining environmental equilibrium and socio-economic upliftment of the people. To keep up the environmental equilibrium a minimum of twenty fifth space of a country should be lined with forest. In Bangladesh the whole forest space covers regarding $13.36 \%$ of the area (BBS, 2001) however the particular tree lined space is calculable at around 5.4\% that is decreasing at a horrific rate (Hossain \& bari, 1996). Due to continuous transformation of forest land to agricultural land, cultivation, homestead and alternative functions, concerning 8000 ha of forest land is decreasing per year (FAO, 1981). On the other hand, in Bangladesh the demand or rood-tree crops increasing speedily because of ever increasing population. The country has only eight.29 million ha of tillable land is to reed 134.3 million people (BBS, 2003). However, the fertility of our land is decreasing 
quickly because of intensive cropping and use of high input technologies. Underneath this dreadful condition, it's necessary to seek out an appropriate various to beat this example. Since there's neither scope for increasing forest space non sole crop areas.

Cropland agro forestry is a production technique or methodology that mixes agricultural crops and forestry on a bit of land to maximize the use of natural resources (land, sunlight, water and nutrition). (Torquesiau, 1994). In a study on cropland agro forestry, it was found that 46 percent of farmers generated cash income from filling trees and meet expenses for purchase of land, bullocks and input for crops, supplemented expenses of marriage, household expenditure, and loan repayment (Chowdhury \& Mahat, 1993). Cropland agroforestry includes trees like species of Eucalyptus camaldulensis, Acacia nilotica, A. albida, A. auriculiformis, Swietenia macrophylla, Dalbergia sissoo, Samanea saman, Casuarina equisetifolia etc. These trees are grown along with various annual crops like rice, wheat, cereals and other cash crops in farmer's land. It is typically assumed that the full production of agro forestry systems is lighter than that of associate annual crop system or forestry alone, as a result of growth resources (light, nutrient, and water) are used expeditiously during this system. Practicing agro forestry system with appropriate tree crop association like Acacia auriculiformis, A. albida and casuarina equisetifolia-rice association will increase total production compared to monoculture system. In agro forestry system, interaction between trees and crops is the heart as a result of sharing of the common resources by completely different species is that the common phenomenon. However, these interactions should take place with respect to how the component of agro forestry utilizes and share the resources of the environment and how the growth and development of any of the components will influence the others (Torquesiau, 1994). The research paper aimed at evaluating the performance of vegetative, yield and yield contributing characters of rice $c v$. BR 11 as under story crop in association with Akashmoni, Albida and Jhau as compared to the open field at different orientations.

\section{Materials and Methods}

The experiment was conducted at the Field Laboratory, Department of Agro forestry, Bangladesh Agricultural University, Mymensingh during July-December, 2004. The soil texture is silty loam (FAO, 1988). The experiment was carried out by two Factorial Randomized Complete Block Design with three replications. Two factors i.e. trees and orientations of the plots from the tree base. Total number of plots in the experiment was 45 . Each unit plots was $2 \mathrm{~m} \times 2 \mathrm{~m}$. Albida, Akashmoni and Jhau trees (three from each) were involved in this experiment. Thirty-six plots were laid under the trees and nine plots were laid in control (open field). The crown diameter of each selected tree was measured along north-south and east-west axis using stick and measuring tape. The crown area of each tree was calculated from crown diameter using the following formula.

$$
C C=\frac{\pi}{4}\left(\frac{D_{1}+D_{2}}{2}\right)^{2} \quad \begin{aligned}
& \text { Where } \\
&
\end{aligned} \quad \begin{aligned}
& \mathrm{CC}=\text { Crown area (cover) of the tree in } \mathrm{m}^{2} \\
& \mathrm{D}_{1}=\text { Crown diameter along north-south axis } \\
& \mathrm{D}_{1}=\text { Crown diameter along east-west axis }
\end{aligned}
$$

The treatment combinations used in this investigation were as follows:

\begin{tabular}{ll}
\hline Factor A: Tree & Factor B: Orientation \\
\hline & $\mathrm{O}_{0}=$ Open field (control) \\
$\mathrm{T}_{1}=$ Albida (Casuarina equisetifolia) & $\mathrm{O}_{1}=$ North ( $1 \mathrm{~m}$ from the tree base) \\
$\mathrm{T}_{2}=$ Akashmoni (Acacia auriculiformis) & $\mathrm{O}_{2}=$ South ( $1 \mathrm{~m}$ from the tree base) \\
$\mathrm{T}_{3}=$ Jhau (Casuarina equisetifolia) & $\mathrm{O}_{3}=$ East (1m from the tree base) \\
& $\mathrm{O}_{4}=$ West (1m from the tree base) \\
\hline
\end{tabular}

On $15^{\text {th }}$ July 2004, the land ploughed and cross-ploughed several times by power tiller until the soil was brought to a good tilth. The fertilizers were applied in the field according to the recommended doses (BRRI, 1998); Urea @180 kg/ha, TSP @125 kg/ha, MP @70 kg/ha, Gypsum @60 kg/ha and Zinc sulphate @ $10 \mathrm{~kg} / \mathrm{ha}$. One third of urea and all other fertilizers were incorporated with soil during 
finally land preparation. Urea was applied in two equal splits. One third after 23 days after transplanting and rest one third before flowering at 48 days transplanting. Thirty-five (35) days old seedlings of BR11 rice were collected from the agricultural farm of BAU. Seedlings were uprooted with care from the slightly irrigated seedbed. Two/three seedlings per hill were transplanting with $15 \mathrm{~cm} \mathrm{x}$ $25 \mathrm{~cm}$ spacing at $4^{\text {th }}$ August 2004. Necessary gap filling was done within 10 days of transplanting. Uprooting and removing from the field controlled weeds. Diazinon 60EC was applied once with urea fertilizer during second installment of top dressing to control insect pests of rice. Top dressing of urea fertilizers was done $1 / 3^{\text {rd }}$ at 30 days after transplanting and $1 / 3^{\text {rd }}$ before flowering. Cop was grown under rain fed condition. Prior to each top dressing, plots were weeded manually. Five hills were randomly selected from each plot at maturity to record the data on yield contributing characters like plant height $(\mathrm{cm})$, numbers of total tiller hill-1, number of effective tillers hill-1, panicle length $(\mathrm{cm})$, number of filled grains/panicle, number of unfilled spikelets panicle-1, 1000-grain weight (g). The selected hills were collected before crop harvest and necessary information's were recorded accordingly. The crop was harvested at its full maturity. The data collected at final harvest were coded and analyzed following the appropriate design of the experiment. Duncan's new multiple range tests were computed in order to show the significant differences between the treatment means (Zaman et al. 1982).

\section{Results and Discussion}

The shading effect of tree-rice association observed on plant height, total number of tiller hill ${ }^{-1}$, effective tillers hill-1, non-effective tillers hill ${ }^{-1}$, sterile spikelet panicle ${ }^{-1}$, effective grain panicle ${ }^{-1}$, total grains panicle ${ }^{-1}$, total grain ( $\left.\mathrm{t} \mathrm{ha}^{-1}\right)$ and straw yield ( $\left.\mathrm{t} \mathrm{ha}^{-1}\right)$ was significant (Table 01$)$. It was recorded that out of the three tree-rice associations, the highest $(105.75 \mathrm{~cm})$ and lowest $(100.21 \mathrm{~cm})$ plant height of rice were found under Albida and Jhau tree, the highest number of effective tillers hill-1 (11.85) was found in Albida tree-rice association and the lowest number of effective tiller (11.04) was found in Akashmoni tree rice-association which is statistically similar with Jhau tree - rice association. In case of non-effective tillers hill-1, the lowest number (1.62) was counted in Akashmoni tree-rice association and the highest number (1.91) was counted in Albida tree-rice association. In regard of effective grain per panicle, it was counted highest (140.65) and lowest (129.42) under Albida and Jhau tree respectively. Sterile spikelets were found lowest (24.77) and highest (29.88) under Akashmoni and Albida tree-rice association respectively. The highest effective grain panicle ${ }^{-1}$ (140.65) found in Albida tree-rice association. The panicle length and weight of 1000-grains was not significantly affected due to different types of tree species. The highest yield of rice $\left(4.88 \mathrm{t} \mathrm{ha}^{-1}\right)$ was recorded in Albida tree-rice association. The lowest grain yield $\left(4.70 \mathrm{t} \mathrm{ha}^{-1}\right)$ was achieved under Akashmoni tree. This result is more or less similar to the finding of Alam et al. (2001). The lowest ( $\left.6.80 \mathrm{t} \mathrm{ha}^{-1}\right)$ and highest ( $7.10 \mathrm{t} \mathrm{ha}^{-}$ 1) straw yield were obtained under Akashmoni and Albida tree (Table 01).

\section{Table 01. Shading effect of trees on vegetative, yield and yield contributing characters of rice cV. BR11}

\begin{tabular}{|c|c|c|c|c|c|c|c|c|c|c|c|}
\hline \multirow[b]{2}{*}{ Trees } & \multicolumn{3}{|c|}{ Vegetative characters } & \multicolumn{8}{|c|}{ Yield and yield contributing characters } \\
\hline & 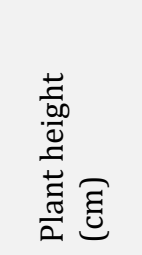 & 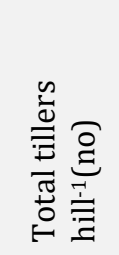 & 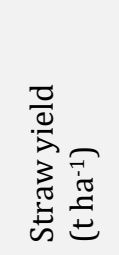 & 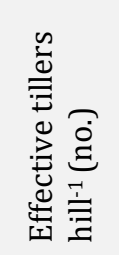 & 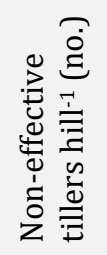 & 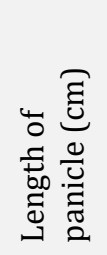 & 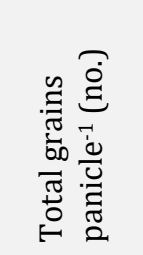 & 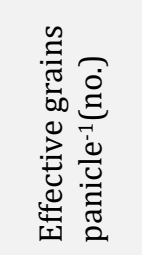 & 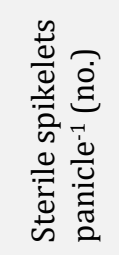 & 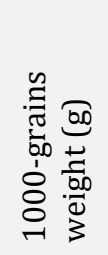 & 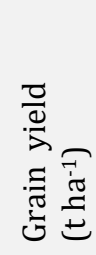 \\
\hline $\mathrm{T}_{1}$ & $105.75 a$ & $4.00 \mathrm{a}$ & $7.10 \mathrm{a}$ & $11.85 \mathrm{a}$ & $1.91 \mathrm{a}$ & 21.61 & $169.66 \mathrm{a}$ & $140.65 a$ & $29.88 \mathrm{a}$ & 23.29 & $4.88 \mathrm{a}$ \\
\hline $\mathrm{T}_{2}$ & $103.14 \mathrm{a}$ & $12.73 c$ & $6.80 \mathrm{~b}$ & $11.04 \mathrm{~b}$ & $1.62 \mathrm{c}$ & 22.12 & $155.11 \mathrm{~b}$ & $130.35 b$ & $24.77 \mathrm{c}$ & 23.29 & $4.70 \mathrm{~b}$ \\
\hline $\mathrm{T}_{3}$ & $100.21 b$ & $13.23 \mathrm{~b}$ & $6.90 \mathrm{ab}$ & $11.37 \mathrm{~b}$ & $1.85 \mathrm{~b}$ & 21.58 & $157.10 \mathrm{a}$ & $129.42 b$ & $27.58 \mathrm{~b}$ & 23.81 & $4.76 \mathrm{ab}$ \\
\hline $\begin{array}{l}\text { Level of } \\
\text { significance }\end{array}$ & 0.01 & 0.01 & 0.05 & 0.05 & 0.01 & $N S$ & 0.01 & 0.01 & 0.01 & $N S$ & 0.05 \\
\hline$C V(\%)$ & 3.76 & 4.03 & 4.11 & 5.33 & 4.68 & 4.57 & 3.70 & 5.55 & 10.41 & 6.15 & 3.96 \\
\hline
\end{tabular}

In a column, figures having the similar letter (s) or without letter (s) do not differ significantly as per DMRT; NS= Not significant; $\mathrm{T}_{1}=$ Albida, $\mathrm{T}_{2}=$ Akashmoni and $\mathrm{T}_{3}=\mathrm{Jhau}$ 
Regarding different orientations from the tree base, the plant height, total tiller hill-1, effective tillers hill- $^{-1}$, non-effective tillers hill- ${ }^{-1}$, and effective grains panicle-1 and grain yield $\left(\mathrm{t} \mathrm{ha}^{-1}\right)$ ) was significant (Table 02). The highest total grain yield $\left(5.00 \mathrm{t} \mathrm{ha}^{-1}\right)$, plant height $(108.92 \mathrm{~cm})$, effective tillers hill-1 (13.07), non-effective tillers per hill (2.23), effective grains panicle ${ }^{-1}$ (144.55) and grain yield was found in $\mathrm{O}_{0}$-orientation (open field). The lowest plant height $(96.11 \mathrm{~cm})$, effective tillers hill-1 $(9.96)$, non-effective tillers hill-1 (1.39), effective grains per panicle (124.27) and grain yield (4.60 t ha-1) was found under $\mathrm{O}_{4}$-orientation (west side from the tree base) which was statistically similar with $\mathrm{O}_{3}$ orientation (East side from tree base) (Table 02). The panicle length, sterile spikelet panicle-1, 1000grains weight, straw yields were not affected significantly due to the orientation (Table 02). Lower grain yield under shade was due to the cumulative effect of reduction in the number of effective tillers hill-1 $^{-1}$, number of grains panicle ${ }^{-1}$ and plant height and increase in sterility of spiekelets, 1000-grains weight. Lower grain yield under shade was due to the cumulative effect of reduction in the number of effective tillers hill-1, number of grains panicle ${ }^{-1}$ and plant height and increase in sterility of spiekelets, 1000 grains weight. Jadhav (1987) and Chaturvedi and Ingram (1989) have reported similar results. Lin and Hung (1979) reported that shading decreased the number of spikelets on the secondary rachis branches and in the lower part of panicle. Nayak and Murty (1980) found that due to low light dry matter producing, panicle number and grains per panicle was decreased.

Table 02. Effect of orientations on vegetative, yield and yield contributing characters of rice cv. BR11

\begin{tabular}{|c|c|c|c|c|c|c|c|c|c|c|c|}
\hline \multirow[b]{2}{*}{ Orientations } & \multicolumn{3}{|c|}{ Vegetative characters } & \multicolumn{8}{|c|}{ Yield and yield contributing characters } \\
\hline & 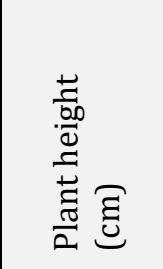 & 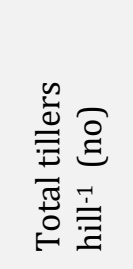 & 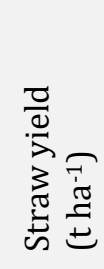 & 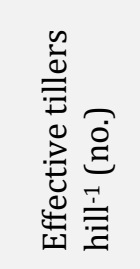 & 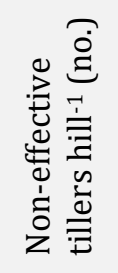 & 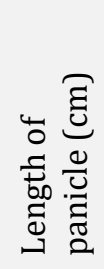 & 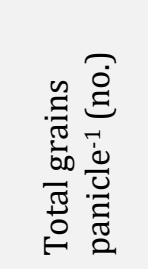 & 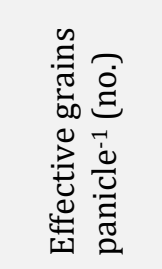 & 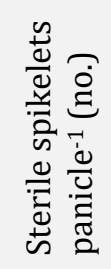 & 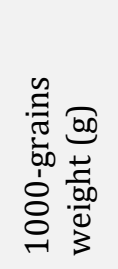 & 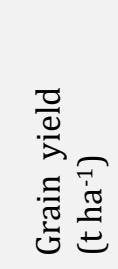 \\
\hline$\overline{\mathrm{O}_{0}}$ & 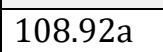 & $15.61 \mathrm{a}$ & 6.87 & $3.07 a$ & $2.23 a$ & 22.10 & $171.85 a$ & $4.55 a$ & 27.07 & 22.80 & $5.00 \mathrm{a}$ \\
\hline $\mathrm{O}_{1}$ & $106.65 \mathrm{ab}$ & $13.97 \mathrm{~b}$ & 7.13 & $11.75 b$ & $2.01 \mathrm{~b}$ & 21.54 & $166.09 \mathrm{~b}$ & $138.31 \mathrm{ab}$ & 27.78 & 22.83 & $4.86 \mathrm{ab}$ \\
\hline $\mathrm{O}_{2}$ & $104.21 \mathrm{~b}$ & $13.09 \mathrm{c}$ & 6.98 & $11.32 \mathrm{bc}$ & $1.78 \mathrm{c}$ & 21.57 & $159.12 \mathrm{c}$ & $131.76 \mathrm{bc}$ & 27.91 & 23.61 & $4.77 \mathrm{bc}$ \\
\hline $\mathrm{O}_{3}$ & $99.26 \mathrm{c}$ & $12.55 \mathrm{~d}$ & 6.87 & $11.00 \mathrm{c}$ & $1.56 \mathrm{~d}$ & 22.01 & $153.25 d$ & $128.45 \mathrm{c}$ & 25.91 & 24.42 & $4.67 \mathrm{c}$ \\
\hline & $96.11 \mathrm{c}$ & $11.35 \mathrm{e}$ & 6.03 & $9.96 \mathrm{~d}$ & $1.39 \mathrm{e}$ & 21.62 & $152.64 d$ & $124.27 \mathrm{c}$ & 28.36 & 23.68 & $4.60 \mathrm{c}$ \\
\hline $\begin{array}{l}\text { Level of } \\
\text { significance }\end{array}$ & 0.01 & 0.01 & $N S$ & 0.01 & 0.01 & $N S$ & 0.01 & 0.01 & NS & NS & 0.01 \\
\hline$C V(\%)$ & 3.76 & 4.03 & 4.11 & 5.33 & 4.68 & 4.57 & 3.70 & 5.55 & 10.41 & 6.15 & 3.96 \\
\hline
\end{tabular}

In a column, figures having the similar letter (s) or without letter (s) do not differ significantly as per DMRT; NS= Not significant; $\mathrm{O}_{0}=$ control (open field), $\mathrm{O}_{1}=$ North, $\mathrm{O}_{2}=$ South, $\mathrm{O}_{3}=$ East and $\mathrm{O}_{4}=$ West

The tree-rice interaction effect significantly found in the vegetative characters i.e. total tiller hill-1 and straw yield hill-1 (Table 03). The highest total tillers hill-1 was produced by the, $\mathrm{T}_{1} \times \mathrm{O}_{0}$ (16.38) which were statistically similar with $\mathrm{T}_{2} \times \mathrm{O}_{0}$ the lowest number of total tillers hill-1 were produced by the $\mathrm{T}_{2} \times \mathrm{O}_{4}$ (11.05) (Table 03). While Interaction of $\mathrm{T}_{1} \times \mathrm{O}_{0}$-orientation produced the highest straw yield ( $7.26 \mathrm{t}$ ha$\left.{ }^{1}\right)$, which was statistically similar with the treatment $\mathrm{T}_{1} \times \mathrm{O}_{1}$ and $\mathrm{T}_{3} \times \mathrm{O}_{0}$. The lowest yield $\left(6.17 \mathrm{t} \mathrm{ha}^{-1}\right)$ was produced by control (Table 03). In regards of yield contributing characters, interaction effect significantly found in effective tiller hill-1, non-effective tiller and sterile spikelet panicle ${ }^{-1}$. While no significant effect found in panicle ${ }^{-1}$, total grain panicle ${ }^{-1}$, effective grain panicle-1, 1000-grains weight and total grain $\left(\mathrm{t} \mathrm{ha}^{-1}\right)$. The highest yield found in $\mathrm{T}_{1} \times \mathrm{O}_{0}$ orientation (5.18 $\left.\mathrm{t} \mathrm{ha}^{-1}\right)$. Similarly Jiang et al. (1994) reported that tree crown had no significant effect on the number of effective spikelets and grains of wheat but it affected total grain yield and 1000-grain weight, with the size of the effect on crop, depending on the distance from the trees which is also supported by Khan and Aslam (1974). 
Table 03. Effect of interaction between trees and orientations on vegetative, yield and yield contributing characters of rice cv. BR11.

\begin{tabular}{|c|c|c|c|c|c|c|c|c|c|c|c|}
\hline \multirow[b]{2}{*}{ 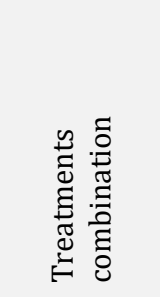 } & \multicolumn{3}{|c|}{ Vegetative characters } & \multicolumn{8}{|c|}{ Yield and yield contributing characters } \\
\hline & 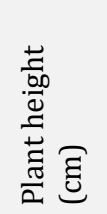 & 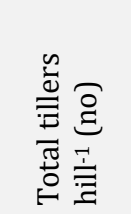 & 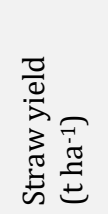 & 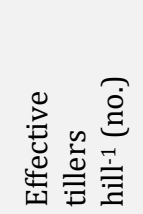 & 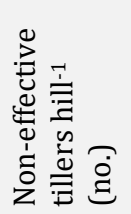 & 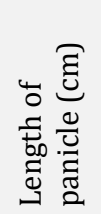 & 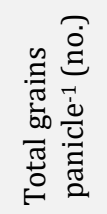 & 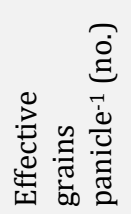 & 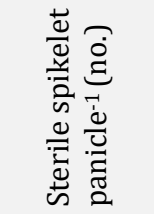 & 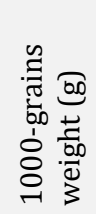 & 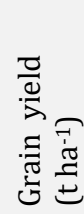 \\
\hline $\mathrm{T}_{1} \times \mathrm{O}_{0}$ & 112.01 & $38 \mathrm{a}$ & $7.31 \mathrm{a}$ & $13.51 \mathrm{a}$ & $2.30 \mathrm{a}$ & 21.21 & 177.45 & 148.90 & $27.89 \mathrm{bcd}$ & 21.98 & 5.18 \\
\hline $\mathrm{T}_{1} \times \mathrm{O}_{1}$ & 108.54 & $15.42 \mathrm{~b}$ & $7.26 a$ & $12.71 \mathrm{ab}$ & $2.10 \mathrm{bc}$ & 21.46 & 173.38 & 143.94 & $29.44 \mathrm{bc}$ & 22.84 & 4.90 \\
\hline $\mathrm{T}_{1} \times \mathrm{O}_{2}$ & 106.91 & $13.87 \mathrm{de}$ & 7.05ab & $11.94 \mathrm{bcd}$ & $1.93 \mathrm{de}$ & 21.50 & 167.57 & 140.20 & $29.04 \mathrm{bc}$ & 23.45 & 4.83 \\
\hline $\mathrm{T}_{1} \times \mathrm{O}_{3}$ & 100.42 & $12.89 \mathrm{f}$ & 6.91ab & 11.12 def & $1.77 \mathrm{f}$ & 22.35 & 160.68 & 137.25 & $26.77 \mathrm{bcd}$ & 25.83 & 4.78 \\
\hline $\mathrm{T}_{1} \times \mathrm{O}_{4}$ & 100.84 & 11.42hi & 6.94ab & $9.96 \mathrm{~g}$ & $1.47 \mathrm{~g}$ & $21 . .52$ & 169.23 & 132.97 & $36.26 a$ & 22.34 & 4.73 \\
\hline $\mathrm{T}_{2} \times \mathrm{O}_{0}$ & 107.19 & $14.91 \mathrm{bc}$ & $6.19 c$ & 12.38abc & $2.20 \mathrm{ab}$ & 22.52 & 169.86 & 142.53 & $27.33 \mathrm{bcd}$ & 22.04 & 4.89 \\
\hline $\mathrm{T}_{2} \times \mathrm{O}_{1}$ & 105.20 & $12.42 \mathrm{fg}$ & 7.08ab & $10.52 \mathrm{efg}$ & $1.90 \mathrm{deg}$ & 21.50 & 164.01 & 135.45 & $28.56 \mathrm{bcd}$ & 23.27 & 4.83 \\
\hline $\mathrm{T}_{2} \times \mathrm{O}_{2}$ & 103.86 & 13.03ef & 6.99ab & $11.43 \mathrm{cde}$ & $1.60 \mathrm{~g}$ & 22.02 & 152.93 & 128.91 & $24.02 \mathrm{cde}$ & 23.40 & 4.72 \\
\hline $\mathrm{T}_{2} \times \mathrm{O}_{3}$ & 101.84 & $12.20 \mathrm{fgh}$ & $6.87 a b$ & 10.90defg & $1.30 \mathrm{~h}$ & 22.29 & 148.24 & 124.91 & 23.34de & 24.13 & 4.59 \\
\hline $\mathrm{T}_{2} \times \mathrm{O}_{4}$ & 97.59 & $11.06 \mathrm{i}$ & $6.90 \mathrm{ab}$ & $9.96 \mathrm{~g}$ & $1.10 \mathrm{i}$ & 22.26 & 140.52 & 119.92 & $20.59 \mathrm{e}$ & 23.63 & 4.49 \\
\hline $\mathrm{T}_{3} \times \mathrm{O}_{0}$ & 107.57 & 15.53ab & $7.14 \mathrm{a}$ & $13.33 a$ & $2.20 \mathrm{ab}$ & 22.58 & 168.24 & 142.24 & $26.00 \mathrm{bcd}$ & 24.37 & 4.94 \\
\hline $\mathrm{T}_{3} \times \mathrm{O}_{1}$ & 106.20 & $14.05 \mathrm{~cd}$ & 7.04ab & $12.02 \mathrm{bcd}$ & $2.03 \mathrm{~cd}$ & 21.68 & 160.90 & 135.54 & $25.35 \mathrm{bcde}$ & 22.38 & 4.87 \\
\hline $\mathrm{T}_{3} \times \mathrm{O}_{2}$ & 101.87 & 12.38fgh & 6.91ab & $10.58 \mathrm{efg}$ & $1.80 \mathrm{ef}$ & 21.17 & 156.86 & 126.18 & $30.68 b$ & 23.97 & 4.78 \\
\hline $\mathrm{T}_{3} \times \mathrm{O}_{3}$ & 95.53 & $12.56 \mathrm{f}$ & 6.83ab & 10.96defg & $1.60 \mathrm{~g}$ & 21.38 & 150.82 & 123.20 & $27.62 \mathrm{bcd}$ & 23.28 & 4.63 \\
\hline $\mathrm{T}_{3} \times \mathrm{O}_{4}$ & 89.90 & $12.56 \mathrm{f}$ & $6.57 \mathrm{bc}$ & $9.96 \mathrm{~g}$ & $1.60 \mathrm{~g}$ & 21.07 & 148.16 & 119.92 & $28.23 \mathrm{bcd}$ & 25.07 & 4.56 \\
\hline $\begin{array}{l}\text { Level of } \\
\text { significance }\end{array}$ & NS & 0.01 & 0.01 & 0.05 & 0.01 & $N S$ & NS & $N S$ & 0.01 & $N S$ & $N S$ \\
\hline$C V(\%)$ & 3.76 & 4.03 & 4.11 & 5.33 & 4.68 & 4.57 & 3.70 & 5.55 & 10.41 & 6.15 & 3.96 \\
\hline
\end{tabular}

In a column, figures having the similar letter (s) or without letter (s) do not differ significantly as per DMRT; NS= Not

significant; $\mathrm{O}_{0}=$ control (open field), $\mathrm{O}_{1}=$ North, $\mathrm{O}_{2}=$ South, $\mathrm{O}_{3}=$ East and $\mathrm{O}_{4}=$ West; $\mathrm{T}_{1}=$ Albida, $\mathrm{T}_{2}=$ Akashmoni and $\mathrm{T}_{3}=\mathrm{Jhau}$

\section{Conclusion}

The base of Albida tree and north-orientation appears as the best than other trees and orientation in this experiment. Rice produced the highest grain yield from the base of Albida tree with northorientation. It's clearly indicated that, choice of species of trees for an agroforestry cultivation system is very significant. Therefore, before making choice, about the shade plants the crop which is usually supposed to be grown repeatedly in association must be taken into account. Beside this weather condition factor of the environment has played a decisive role on the parameters. Thus, such experiments should be repeated several times on the some field and also at different agro-ecological zones before drawing a precise and formulating suggestive strategy for the general farmers.

\section{Reference}

[1]. Alam, A. S. M. M., Wadud, M. A., Islam, K. K., Hossain, K. L. \& Rahman, G. M. M. (2001). Effect of trees growing in association with BR 11 on the yield and yield contributing characters of rice in cropland agroforestry system. Progressive Agriculture, 12(1\&2), 41-45.

[2]. BBS. (2001). Statistical Yearbook of Bangladesh. Bangladesh Bureau of Statistics, Statistics Division; Ministry of Planning. Government of the People Republic of Bangladesh, Dhaka, Bangladesh.

[3]. BBS. (2003). Statistical Yearbook of Bangladesh. Bangladesh Bureau of Statistics, Statistics Division; Ministry of Planning. Government of the People Republic of Bangladesh, Dhaka, Bangladesh.

[4]. BRRI. (1998). Annual Report for 1996. Bangladesh Rice Research Institute. Joydevpur, Gazipur, Bangladesh Publication No. 3. p. 88.

[5]. Chaturvedi, G. S. \& Ingram, K. T. (1989). Growth and yield of low land rice in response to shade and drainage. Philippine Journal of Crop Science, 147(2), 61-67.

http://www.cabi.org/gara/FullTextPDF/Pre2000/19920758132.pdf 
[6]. Chowdhury, M. K. \& Mahat, T. B. S. (1993). Agroforestry in farming systems of Bangladesh. In: Agroforestry-Farming Systems Linkages in Bangladesh. Chowdhury, M. K. and Mahat, T.B.S. (eds.), BARC-Winrock International Dhaka. pp. 1-19.

[7]. FAO. (1981). Tropical forestry resources assessment project (GEMD): Tropical Africa, Tropical Asia, Tropical America (4 vol.). FAO/UNDP, Rome.

[8]. FAO. (1988). Land resources Appraisal of Bangladesh Agricultural Development reports 2. Agroecological Region of Bangladesh. pp. 212-221.

[9]. Hossain, S. M. A. \& Bari, M. N. (1996). Agroforestry farming system. In: Agroforestry in Bangladesh (Hoque, M. A. ed.) Village \& Farm Forestry Project. SDC. Dhaka \& Bangladesh Agricultural University, Mymensingh. pp. 21-29.

[10]. Jadhav, B. B. (1987). Effect of partial shading on the yield of rice. Indian Journal of Agricultural Sciences, 57(7), 193-205.

[11]. Jiang, J., Zhu J., Liu, T., He, S., Zhou, Z. \& Su, F. (1994). Related change of wheat yield and photo synthetically active radiation in Paulownia tree and wheat intercropping system. Acta Agriculturae Boreali-Sinica, 9, 133-137. http://europepmc.org/abstract/CBA/265968

[12]. Khan, G. S. \& Aslam, R. M. (1974). Extend of Damage wheat by Sissoo proceedings of the Pakistan Forestry Conference (Nov. 4-8, 1974) Pakistan Forest Ins. Peshowar, pp. 37-40

[13]. Lin, A. C. \& Hung, L. M. (1979). Studies on the cause of low yield in the second crop of rice. Journal of the Agricultural Association of China, 6, 10-12.

[14]. Nayak, K. S. \& Murty, K. S. (1980). Effect of varying light intensities on yield and growth parameters in rice. Indian Journal of Plant Physiology, 23, 309-316.

[15]. Torquesiau, E. (1994). Ecological interactions in Agroforestry. Lecture Note, Introduction training Course. ICRAF. pp. 1-36.

[16]. Zaman, S. M. S., Rahim, K. \& Howlader, M. (1982). Simple lessons from Bbiometry. Bangladesh Rice Research Institute. Publication No. 54. p. 88.

Submit article and publish with Journal BiNET.

Key Features:

$\checkmark \quad$ Faster processing and review of article

$\checkmark \quad$ Quick review and editorial tasks

$\checkmark \quad$ International editorial and review board

$\checkmark \quad 21$ business day's rapid publication

$\checkmark \quad$ View and read articles powered by Scribd

$\checkmark \quad$ Greater audience readership is ensured for all article

$\checkmark \quad$ Indexing and bibliographic integration of article

$\checkmark \quad$ Social sharing enabled article

Submit article (or email to submit@ journalbinet.com): http://www.journalbinet.com/article-submission-form.html 